
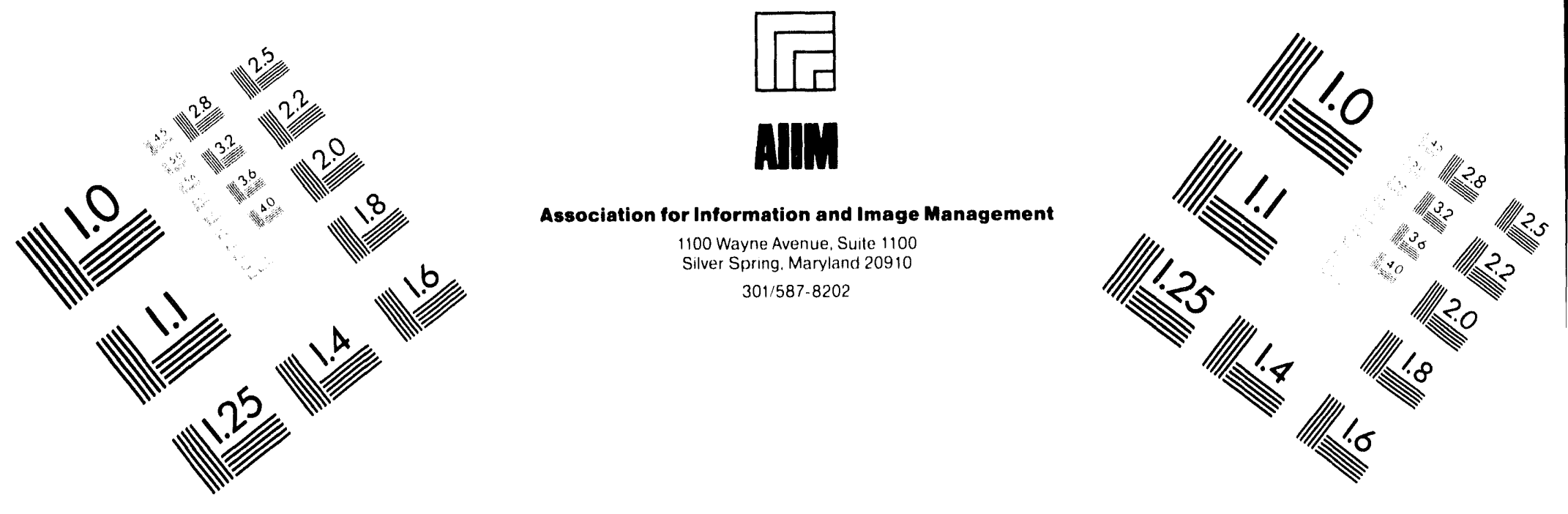

\title{
Centimeter
}

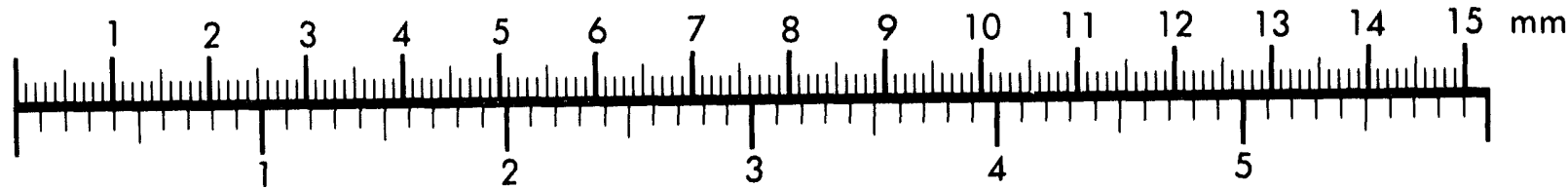

Inches
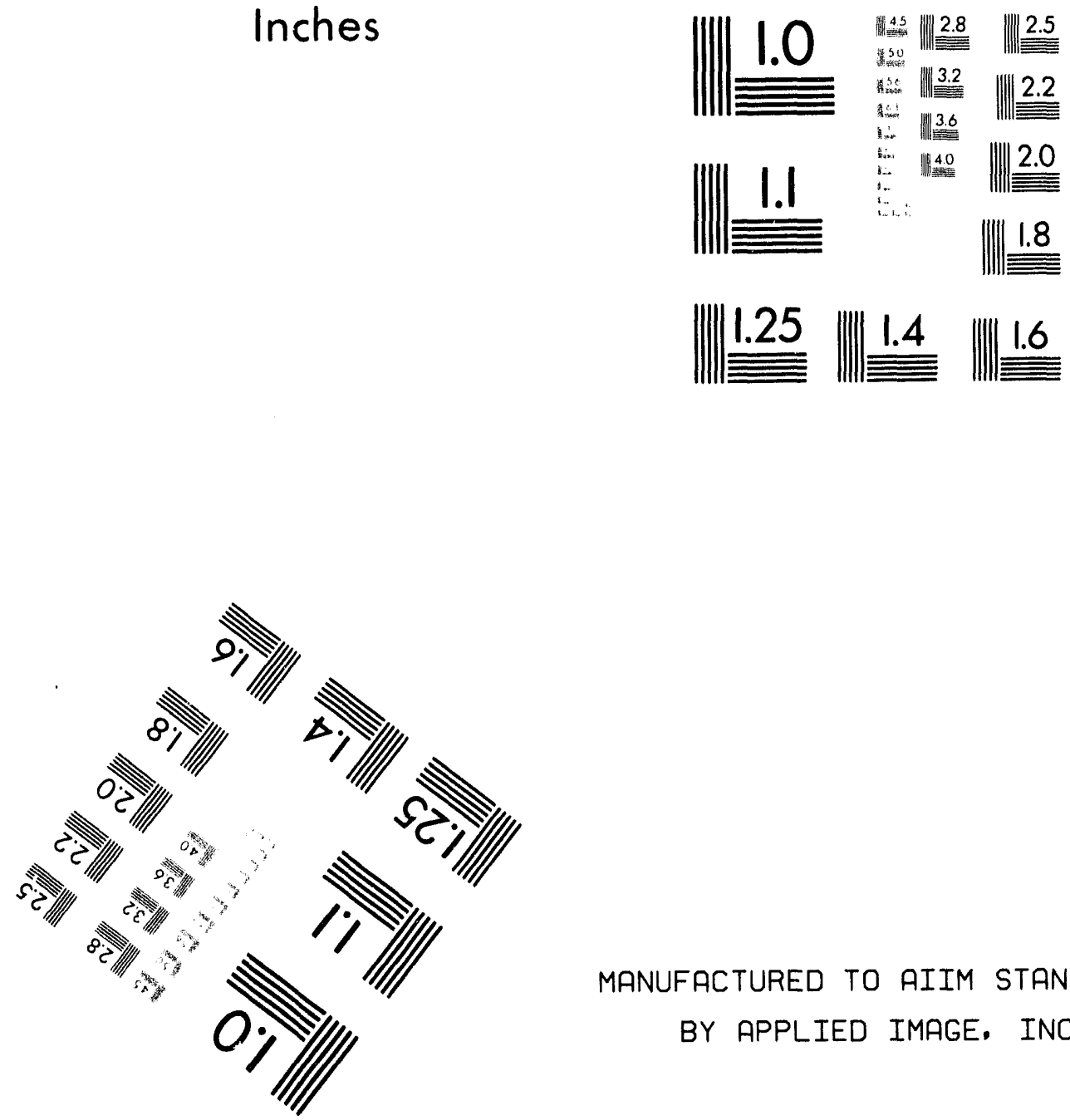

MANUFACTURED TO AIIM STANDARDS

BY APPLIED IMAGE, INC.

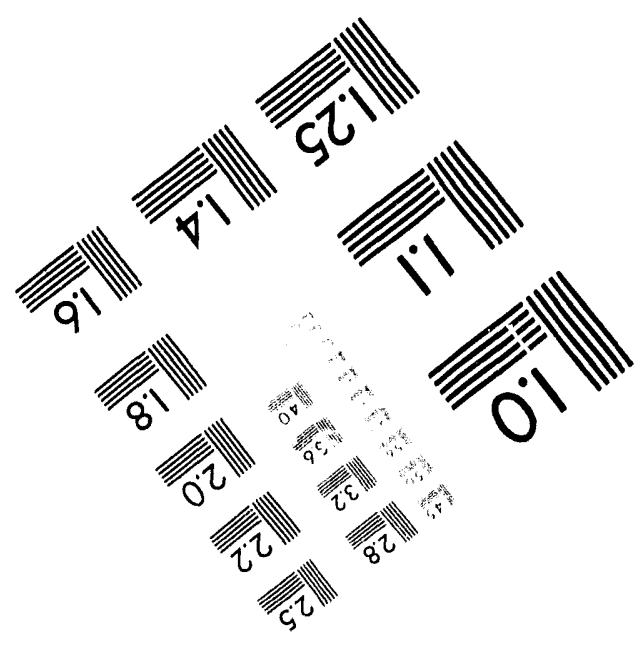



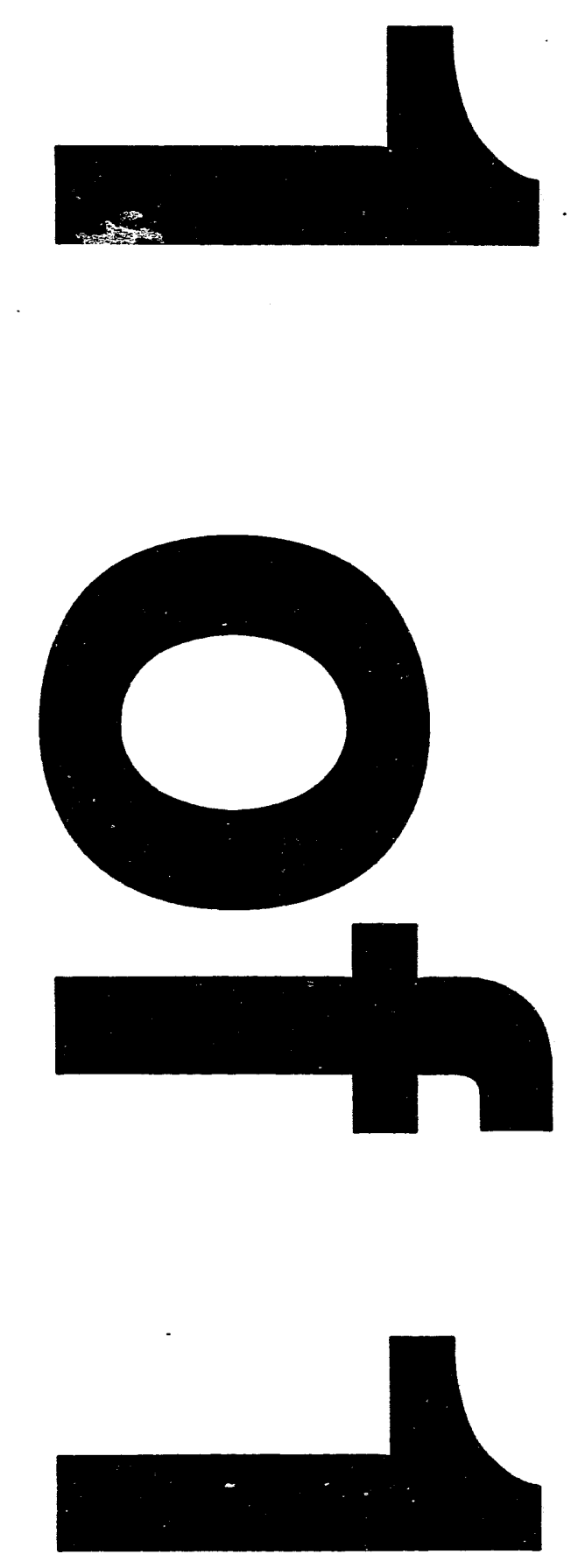


\section{FLOW INSTABILITY AND CRITICAL HEAT FLUX IN A RIBBED ANNULUS}

by

D. A. Coutts

Westinghouse Savannah River Company

Savannah River Site

Alken, South Carolina 29808

B. W. Yang

T. Dougherty

C. Fighetti

S. Kokolis

G. D. Reddy

E. V. McAssey, Jr.

A document prepared for:

10th Internation Heat transfer Conference

at Brighton, United Kingdom

from $8 / 14 / 94$ thru $8 / 18 / 94$

This paper was prepared in connection with work done under the above contract number with the U. S.

Department of Energy. By acceptance of this paper, the publisher and/or recipient acknowledges the U. S.

Government's right to retain a nonexclusive, royalty-free license in and to any copyright covering this paper, along with the right to reproduce and to authorize others to reproduce all or part of the copyrighted paper. 


\section{DISCLAIMER}

This report was prepared as an account of work sponsored by an agency of the United States Government. Neither the United States Government nor any agency thereof, nor any of their employees, makes any warranty, express or implied, or assumes any legal liability or responsibility for the accuracy, completeness, or usefulness of any information, apparatus, product, or process disclosed, or represents that its use would not infringe privately owned rights. Reference herein to any specific commercial product, process, or service by trade name, trademark, manufacturer, or otherwise does not necessarily constitute or imply its endorsement, recommendation, or favoring by the United States Government or any agency thereof. The views and opinions of authors expressed herein do not necessarily state or reflect those of the United States Government or any agency thereof.

This report has been reproduced directly from the best available copy.

Available to DOE and DOE contractors from the Office of Scientific and Technical Information, P. O. Box 62, Oak Ridge, TN 37831; prices available from (615) $576-8401$.

Available to the public from the National Technical Information Service, U. S. Department of Commerce, 5285 Port Royal Rd., Springfield, VA 22161 
FLOW INSTABILITY AND CRITICAL HEAT FLUX IN A RIBBED ANNULUS

B. W. Yang, T. Dougherty, C. Fighetti, S. Kokolis, and G. D. Reddy

Columbia University, New York, NY

E. V. McAssey, Jr.

Villanova University, Villanova, PA

A. Coutts

Westinghouse Savannah River Co., Aiken, SC

\begin{abstract}
An experimental program has been conducted to determine the onset of flow instability point in a heated annulus which is divided into four sub channels by non-conducting ribs. The onset of flow instability is identified by the minimum point in the pressure dropvelocity curve. Comparisons with a ribless annulus show that the presence of ribs increases the minimum point velocity. In addition, data are presented which show that under certain conditions premature CHF can be induced by the ribs.
\end{abstract}

Nomenclature

$q^{\prime \prime}=$ heat flux, $\mathrm{W} / \mathrm{m}^{2}$

$A_{h t}=$ heat transfer area, $\mathrm{m}^{2}$

$\dot{m}=$ mass flow rate, $\mathrm{kg} / \mathrm{sec}$.

$C_{p}=$ specific heat, $\mathrm{J} / \mathrm{kg}-\mathrm{K}$

$T_{\text {sat }}=$ saturation temperature based upon exit pressure, $\mathrm{K}$

$T_{\text {inlet }}=$ inlet temperature, $\mathrm{K}$

$\mathrm{D}=$ diameter, $\mathrm{m}$

$\mathrm{L}=$ heated length, $\mathrm{m}$

$\mathrm{St}=$ Stanton number

1. Introduction

For reactors operating at low pressure, excursive flow instability, Ledinegg instability, generally establishes accident analysis operating limits. Ledinegg instability occurs in a boiling system because void formation can increase the channel pressure drop as the flowrate decreases. In the presence of alternate flow paths, the potential exists to divert the flow from the voiding channel, resulting in channel burnout. The present experimental program was part of an extensive effort to investigate excursive instability under down-flow conditions which simulated the production reactors at the Savannah River Laboratory. 
The demand curve, channel pressure drop versus flowrate or velocity, is generally used $\because$ to identify this type of instability. As the channel velocity decreases, the normal single phase component of the pressure drop decreases; however, voids can form, even under subcooled conditions, and become an increasing pressure drop factor. The resulting demand curve then develops a minimum point, and the increase in pressure drop beyond the minimum point in a parallel system can cause the flow to divert to the alternate flow path. Since the pressure drop versus velocity curve is negative in this region, the system is unstable, and the minimum point is defined as the onset of flow instability (OFI) point.

Marshek (1958) presented the earliest data for Ledinegg instability in down-flow. This program involved the testing of short, small diameter tubes at relatively high heat fluxes. Dougherty et al. (1989), (1990) presented results for $2.4 \mathrm{~m}$ single tube experiments over a test section exit pressure range from $241 \mathrm{kPa}$ to $448 \mathrm{kPa}$ with surface heat flux up to $3.155 \mathrm{MW} / \mathrm{m}^{2}$. These test results showed that the OFI flowrate was a function of $\mathrm{LD}$. In addition, it was shown that the test results could be correlated in terms of the ratio of surface heat flux to the heat flux required to raise the fluid exit temperature to saturation. This ratio was defined as the $\mathrm{Q}_{\text {ratio }}$ (Dougherty et al. 1990). Additional tests were performed in the single tube facility using non-uniformly heated tubes (Dougherty et al. 1990). The presence of non-uniform heating had a small effect on the OFI flowrate. With the same average flux profile, the tubes with higher heating rates in the exit region had OFI flowrates slightly higher than the corresponding uniform tube conditions.

As part of the overall down-flow experimental program, tests were also conducted in a vertical annulus with and without ribs. Fighetti et al. $(1991,1992)$ presented results for the ribless annulus with the same geometry as the present paper. Fighetti et al. (1991) presented steady state OFI data for both symmetric and non-symmetric heating. The experimental data was correlated using the $\mathrm{Q}_{\text {ratio }}$ developed in the earlier, single tube experiments. However, the observed OFI $Q_{\text {ratio }}$ was somewhat higher than that obtained for a single tube with approximately the same $L / D$ ratio. A higher $\mathrm{Q}_{\text {ratio }}$ corresponds to the lower OFI flowrate. It has been postulated that this difference is due to the larger diameter of the annular test section. In larger diameter test sections, more voids would be required to affect the test section pressure drop. Non-symmetric heating, which causes higher surface fluxes as compared to a symmetric case with the same average power, tends to increase the flow-rate at which the minimum point occurs ( Fighetti et al. 1991). Transient test results showed that a greater than $10 \%$ overshoot in the $Q_{\text {ratio }}$ was required before flow instability occurred ( Fighetti et al. 1992).

A significant observation of all these downflow experiments was the minimum poin: in the demand curve (OFI point) occurred at a flowrate very close to the predicted onset of significant voiding flowrate, based upon the Saha-Zuber correlation (Saha and Zuber 1974). Lee Dorra, and Bankoff (1992) also made the same observation considering a slightly larger data base.

Ribbed annular flow instability data, using a test section geometry very close to the present one, was obtained by Block et al. (1990). These investigators conducted experiments in both ribbed and ribless annuli at operating conditions similar to those 
used in the present program. The geometry used in this reference for the ribless case exactly matched the present ribbed geometry. The corresponding OFI results agreed very well. The ribbed OFI flowrates fell considerably below the ribless results. However, it was reported (by Block et al. 1990) that some eccentricity may have existed in the test section causing one channel to be significantly smaller than the other.

\section{Test Loop Facility and Test Section Physical Description}

\subsection{Flow Loop Description}

Figure 1 presents a schematic of the flow loop. Two centrifugal pumps, capable of producing approximately $0.05 \mathrm{~m} / 3 / \mathrm{sec}$. were operated in parallel to provide the flow required under various operating conditions.

The heated test section was located between the inlet and exit plena. The inlet plenum had two inlet ports and four exit ports. One exit port connected directly to the test section. The other ports connected to various bypass lines. One bypass line connected the inlet plenum to the mixing tank. This direct bypass from the inlet plenum to the mixing tank was necessary because the heat exchanger located downstream of the exit plenum could not handle the maximum bypass flow.

The main flow stream leaving the exit plenum was directed to a plate type heat exchanger which was used as the primary equipment for removing energy from the system. Four additional shell and tube type heat exchangers were also used for auxiliary heat rejection.

Depending upon the mode of operation, flow control was accomplished either by a motorized valve located upstream of the inlet plenum or by valves located in the bypass lines. The latter valves include one air-operated, butterfly valve for gradual adjustment and one electrically operated, quick acting valve for rapid transient flow control. The test section inlet temperature was controlled by adjusting the loop external heat rejection rate. The air-operated valve on the secondary side (cooling water line) of the plate heat exchanger was used as the primary temperature control unit. A microprocessor-based expert controller was used to regulate the control valve for temperature control. The system pressure was maintained by adjusting the liquid level and by varying the helium blanket pressure in the surge tank.

\subsection{Test Section Description}

The annular test section (see figure 2) was composed of two inconel 625 tubes. The total heated length of each tube was 3.66 meters. The outside diameter of the inner tube was $59.61 \mathrm{~mm}$, and the inside diameter of the outer tube was $73.64 \mathrm{~mm}$. The wall thickness of both tubes was $1.651 \mathrm{~mm}$. Each tube was capable of producing a thermal flux of 3.155 $\mathrm{MW} / \mathrm{m}^{2}$ independently. 
Two types of annular test sections were investigated. The first test section was a simple annulus with the inner and outer tubes separated by insulated pins. The size and number of pins were been selected to minimize the disturbance to the flow. Each heater tube was rolled from a single sheet of inconel, and then the seam was welded. In order to maintain the required orientation, these tubes were manufactured to very tight tolerances on ovality and straightness. Table 1 presents the geometric parameters for both types of test sections.

Outer Heater Inside

Diameter

Inner Heater Outside

Diameter

Flow Area

Hydraulic Diameter

Heated Length
Table 1 Test Section Geometry

Test Section w/o ribs

$73.64 \mathrm{~mm}$

$59.61 \mathrm{~mm}$

$0.001467 \mathrm{~m}^{2}$

$3.66 \mathrm{~m}$
Test Section with ribs $73.46 \mathrm{~mm}$

$59.61 \mathrm{~mm}$

$0.001407 \mathrm{~m}^{2}$

$12.52 \mathrm{~mm}$

$3.66 \mathrm{~m}$

The ribbed annulus was manufactured in the same manner except that before assembly four ribs were mounted on the inner cylinder. The ribs were a phenolic insulating material. Each rib was $1.588 \mathrm{~mm}$ by $6.35 \mathrm{~mm}$ in cross section. Individual ribs were mounted in clip assemblies located in the four quadrants along the entire heated length and calming length.

\section{Results and Discussion}

As noted earlier, the main objective was to determine the OFI velocity for the ribbed annulus. Figures 3 and 4 present typical pressure drop versus velocity (demand curves) curves for two different test section exit pressures. Decreasing the exit pressure lowers the local saturation temperature, which results in a higher OFI velocity. Data in these figures are presented for each sub-channel. The excellent agreement between subchannels shows that very little eccentricity exists. Figures 3 and 4 also contain ribless heater results, which indicate that the presence of ribs causes the minimum point to occur at a higher velocity. This effect is probably due to a smaller channel hydraulic diameter and a slightly higher local flux resulting from the blocking effect of the ribs. Figure 5 presents the fluid exit temperature measurement in both types of channel. The ribbed channel has a higher exit temperature for the same velocity and flux because of its lower mass flowrate.

Earlier single tube studies (Dougherty et al. 1990, 1991) have shown that the data can be correlated in terms of the $Q_{\text {ratio }}$ which is defined in equation (1).

$$
Q_{\text {ratio }}=\frac{q^{\prime \prime} A_{h t}}{\dot{m} C_{p}\left(T_{\text {sat }}-T_{\text {inlet }}\right)}
$$


Figures 6 and 7 show that the annular data can also be correlated with the same expression. In figure 7, the OFI point for the ribbed heater occurs at a $\mathrm{Q}_{\text {ratio }}$ below 0.9 , compared to a value above 0.96 for the ribless case. Figure 8 presents a comparison of all uniformly heated single tube and annular data using $\mathrm{Q}_{\text {ratio }}$ and $\mathrm{L} / \mathrm{D}$. The latter factor has been shown by both Whittle and Forgan (1967), and Dormer and Bergles (1964) to be the primary geometry parameter in this type of instability. Dormer and Bergles (1964) also noted that a secondary factor was the channel diameter. The addition of ribs decreases the channel hydraulic diameter. This may be the main reason for the reduction of $\mathrm{Q}_{\text {ratio }}$ shown in figure 8. A comparison of the present ribbed results and the ribless results of Block et al. (1990) provides an interesting comparison.. For the same L/D ratio and effective diameter, the $\mathrm{Q}_{\text {ratio }}$ for each set of data agrees. From figure 8, it can also be seen that the ribbed data of Block et al. (1990) is below the expected level based upon the remaining data set. This reference indicated that misalignment was a problem for the ribbed test section. If one of the sub channels is smaller, it would reach flow instability prematurely. This would result in a lower OFI $Q_{\text {ratio. }}$. Finally, figure 8 shows that the Saha-Zuber correlation, modified as shown in equation (2) is a good predictor of the $Q_{\text {ratio }}$ at OFI. Since the Peclet number for all test conditions is greater than 100,000 , the Stanton number in equation (2) is equal to 0.0065 (Saha and Zuber 1974).

$$
Q_{\text {ratio }}=\left(1+\frac{0.25 D}{S t L}\right)^{-1}
$$

By blocking the cooling of the heaters in the region under the rib, the effect of the rib can be much more significant. In addition, the corners formed by the intersection of the rib and heater surfaces produce a region of low velocity. Both these effects produce a local flux peaking in the region of the rib. This peaking can result in local overheating and even CHF. In figure 9 with a $1.89 \mathrm{MW} / \mathrm{m}^{2}$ flux, the sharp increase in wall temperature near the exit of the heater is clearly visible. However, this was not a CHF condition. Figure 10 presents a case in which a wall temperature excursion occurred and the power system tripped. In this case, the OFI point and CHF occurred at the same point. In this pressure range, CHF is essentially a linear function of velocity. The higher exit pressure in figure 10 suppresses the OFI point to a lower velocity. Figure 11 presents a comparison of essentially the same conditions with and without ribs. Although the flux for each case is the same, the ribs cause a local over heating and a significant temperature excursion.

During this test program CHF occurred three time with the last event destroying the test section. Figure 12 presents the heat flux versus inlet velocity for all the OFI points and the three CHF points. The ribless heater did not experience any CHF and in two cases achieved velocities below which CHF occurred in the ribbed heater. The linear variation of CHF with velocity can also be seen in figure 12 . The CHF point shown at the lowest velocity occurred on the inner heater under a non symmetric heating case in which all the power was on the inner tube. The thermocouples on this tube were too slow responding, and physical burnout occurred. Pressure drop data for this run indicates that OFI was also achieved. The CHF point for a flux of $2.5 \mathrm{MW} / \mathrm{m}^{2}$ in figure 12 occurs at a velocity 
well above any expected or measured OFI. Figure 12 also presents a ribless heater $\mathrm{CHF}$ correlation given by Knoebel et al. (1971). The ratio of predicted ribless CHF to measured ribbed CHF is approximately 1.8 .

Ana'ytical studies were conducted to determine the effect the ribs on the heat transfer in the annulus. An initial model which used a zero heat transfer coefficient under the rib and a uniform coefficient away from the rib yielded flux peaks that were too high $(>2.5)$. A more refined model which was based on a variable heat transfer coefficient in the region away from the rib resulted in more reasonable flux peaks. Parametric studies using various heat transfer coefficient profiles showed that the flux peaked about two to three rib thickness away from the rib Post test examination showed that the burnout of the inner heater occurred adjacent to a rib at a location approximating the predicted heat flux peak point. In additon, the predicted peak for the experimental conditions was approximately 1.7 to 1.8 which agrees with figure 12 .

\section{Conclusions}

Experimental results have been obtained which show that the velocity at the onset of flow instability in a ribbed annulus is higher than that measured in a ribless geometry for the same operating conditions. The results also show that the data is well correlated by the $Q_{\text {ratio }}$ defined in equation (1).

For at least one set of geometry, it appears that the decrease in $\mathrm{Q}_{\text {ratio }}$ is more a diameter rather than a rib effect. However, more experimental data is required to verify this conclusion.

The main effect of the ribs is the development of local flux peaking, which can cause the test section to experience CHF. Data obtained on ribless geometry showed that for the same operating conditions no CHF occurred.

The limited CHF data indicated that the local flux peaking factor was approximately 1.8, which agrees with analytical estimates.

\section{Acknowledgment}

Funding for this program was provided by the Savannah River Laboratory under Westinghouse Savannah River Co. Contract AX-721092. The authors wish to express their appreciate to their colleagues at the Heat Transfer Research Facility who assisted in the design, construction, and operation of the test facility. In additions, the authors acknowledge the analytical studies conducted by Dr. G. Jones of Villanova University.

\section{References}

Block, J.A., Crowley, C.J., Dolan, F.X., Sam, R.G., and Stoedefalke, B.H. 1990, Nucleate Boiling Pressure Drop in an Annulus, vol. 1, Creare Report No. TN-499. 
Dormer, J. Jr., and Bergles, A.E., 1964, Pressure Drop with Surface Boiling in Small Diameter Tubes, Report No. 8767-31, Department of Mechanical Engineering, MIT.

Dougherty, T., Fighetti, C., McAssey, E., Reddy, G., Yang, B., Chen, K., Qureshi, Z., 1989, Flow Instability in Vertical Down-Flow at High Fluxes, Heat Transfer in High Energy/High Heat Elux Applications. HTD-Vol. 119, ASME Winter Annual Meeting, San Francisco, CA, pp 17-23.

Dougherty, T., Fighetti, C., Reddy, G., Yang, B., Jafri, T., McAssey, E., Qureshi, Z., 1990, Flow Boiling in Vertical Down-Flow, Proceedings of the Ninth International Heat Transfer Conference Jerusalem. Israel, vol. 2.

Dougherty, T., Fighetti, C., Reddy, G., Yang, B., McAssey, E., Qureshi, Z., 1990, Flow Instability in Non-uniformly Heated Channels, 6 th Miami International Symposium on Heat and Mass Transfer Miami. FL.

Fighetti, C, Kokolis, S., Maciuca, C., Reddy, D., Yang, B., McAssey, E., Qureshi, Z. 1991, Down-Flow Boiling Instability in a Verical Annulus, Proceedings of the 1st ISME/ASME Joint International Conference on Nuclear Engineering Tokyo. Japan, vol. 1.

Fighetti, C., Kokolis, S., Maciuca, C., McAssey, E., Reddy, G.D., Yang, B.W., Carrano, V., and Qureshi, Z. 1992, Flow Instability in a Vertical Annulus Under Steady State and Transient Conditions, AIChE Symposium Series 288, vol. 88.

Knoebel. D.H., Harris S.D., and Biderman, R.M. 1971, Forced Convection Subcooled Critical Heat Flux, 12th National Heat Transfer Conference, Tulsa OK.

Lee, S. C., Dorra, H. and Bankoff, S. G., A Critical Review of Predictive Models for the Onset of Significant Voiding in Forced Convection Subcooled Boiling, Eundamentals of Subcooled Elow Boiling. HTD-vol. 217 ASME Winter Annual Meeting, Anahiem. CA 1992.

\footnotetext{
i a

Młrshek, S., 1958, Transient Flow of Boiling Water in Heated Tubes, Dupont Report , Savannah River Laboratory DP-301TL.

Saha, P., and Zuber,N., Point of Net Vapor Generation and Vapor Void Fraction in Subcooled Boiling, Proceedings of the 5th International Heat Transfer Conference.Tokyo. Paper, B4.7.
}

Whittle, R.H., and Forgan, R., 1967, A Correlation for the Minima in the Pressure Drop Versus Flow-Rate Curves for Sub-Cooled Water Flowing in Narrow Heated Channels, Nuclear Engineering and Design. Vol. 6 pp 89-99. 


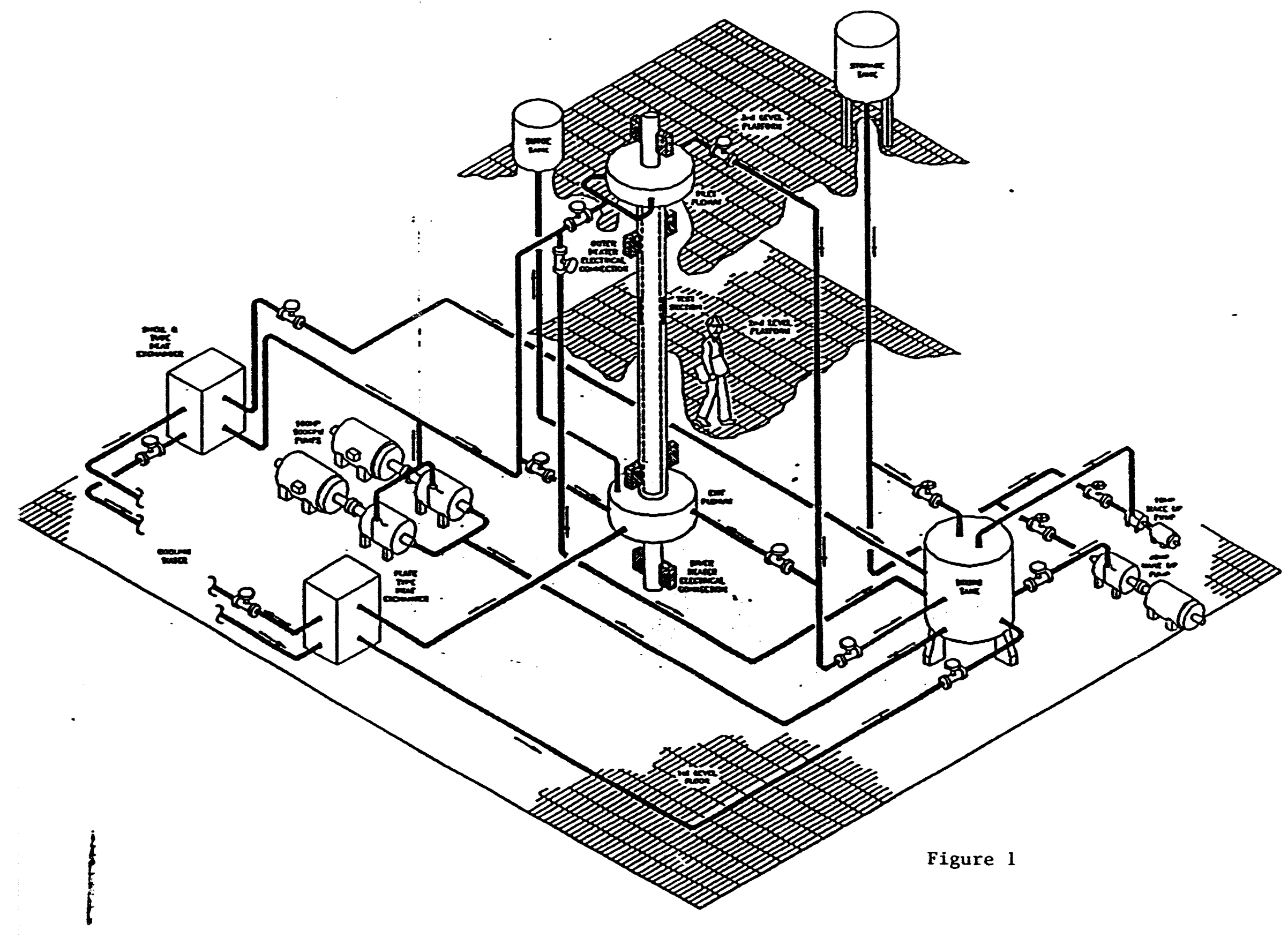


SRL SINGLE ANNULUS TEST SECTION INSTRUMENT ARRANGEMENT

TEST NO.: SA-3.2

MATERIAL: INCONEL 625
TUBE NO.: $3.013-005$ INNER HEATER I0: $2.217^{*}$

OUTER HEATER ID: $2.892^{\prime \prime}$
$O D: 2.347^{n}$

OD: $3.022^{n}$

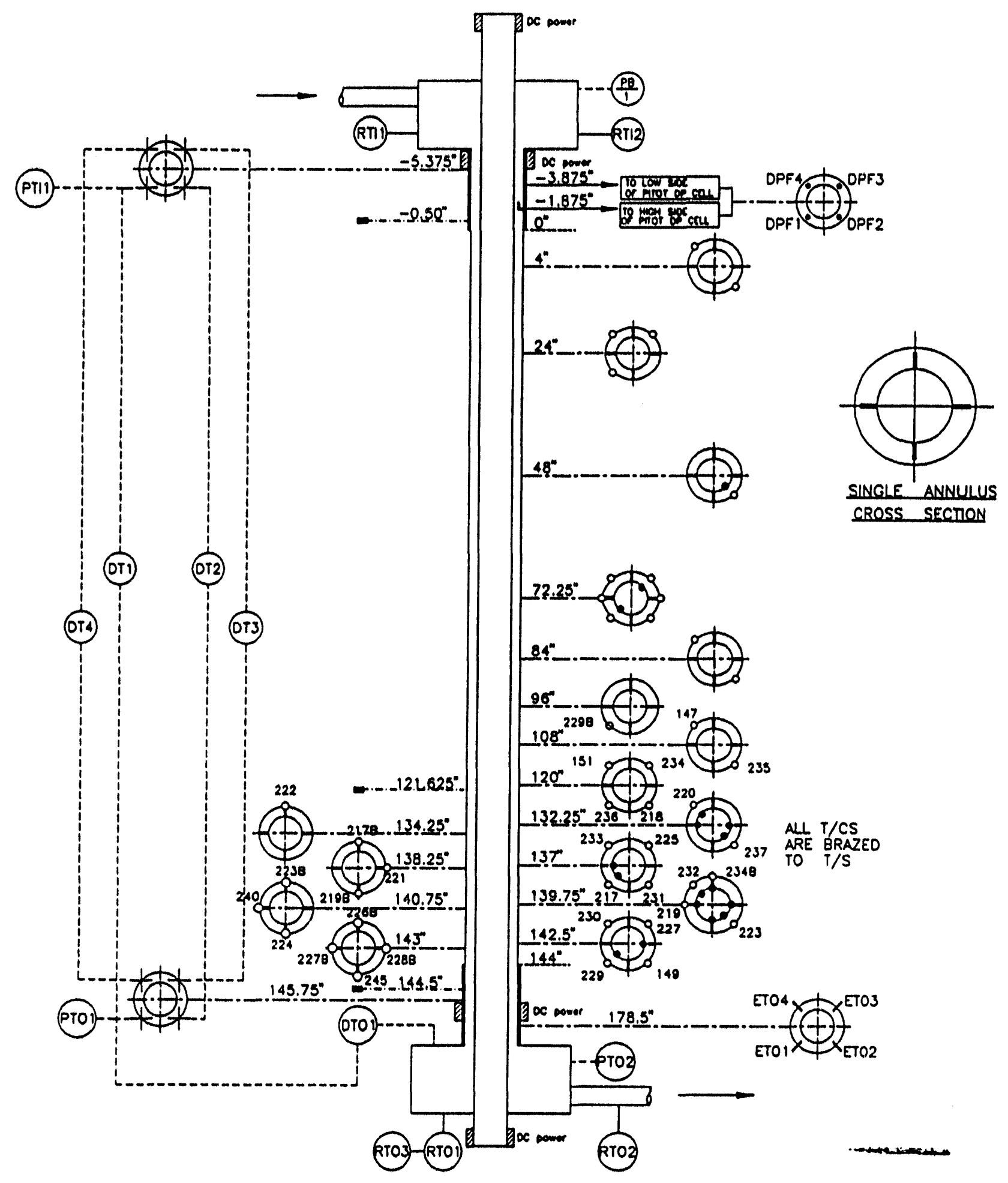

aroce hu: Bewsta
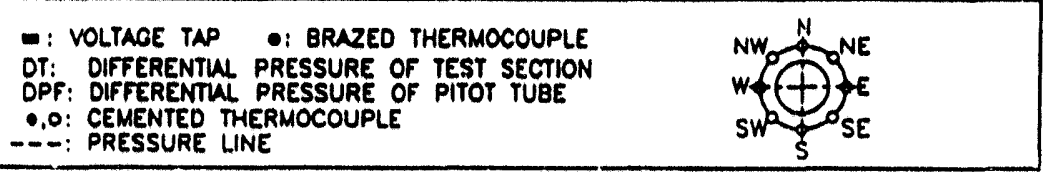


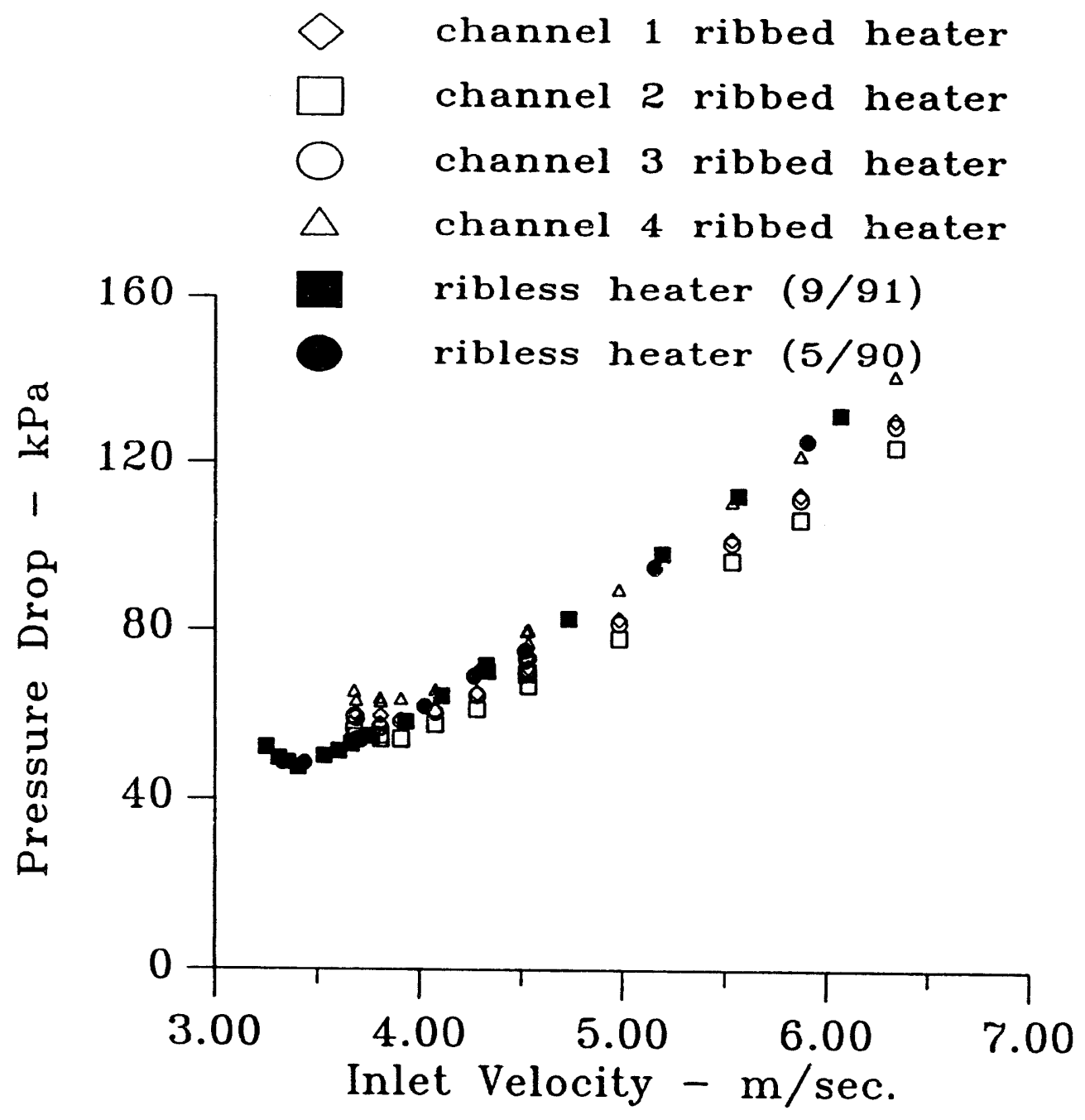

Figure 3 Pressure drop versus velocity

$$
\begin{aligned}
& \mathrm{P}_{\text {exit }}=448 \mathrm{kPa}, \mathrm{T}_{\text {inlet }}=50^{\circ} \mathrm{C} \\
& \text { flux }=1.26 \mathrm{MW} / \mathrm{m}^{2}
\end{aligned}
$$




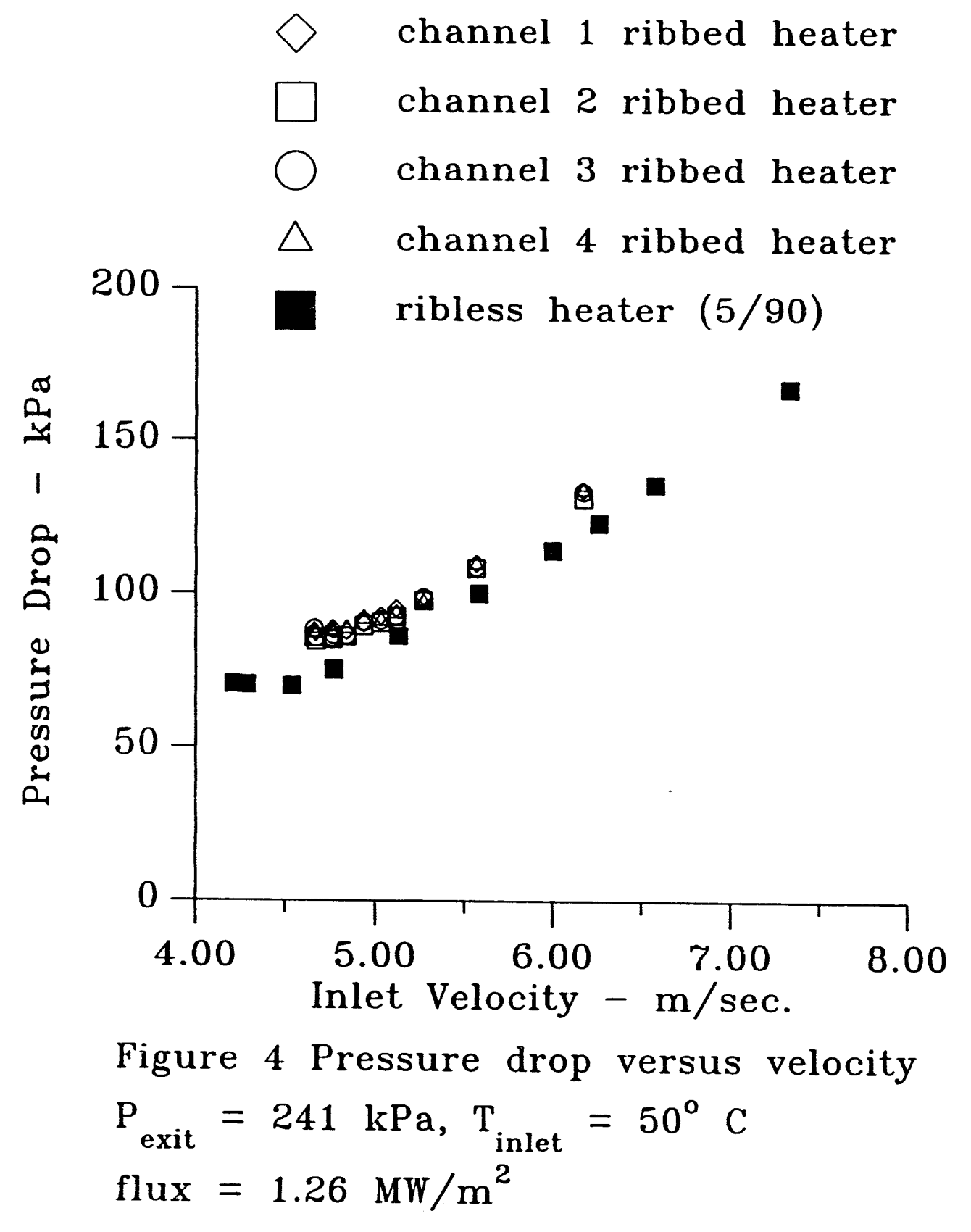




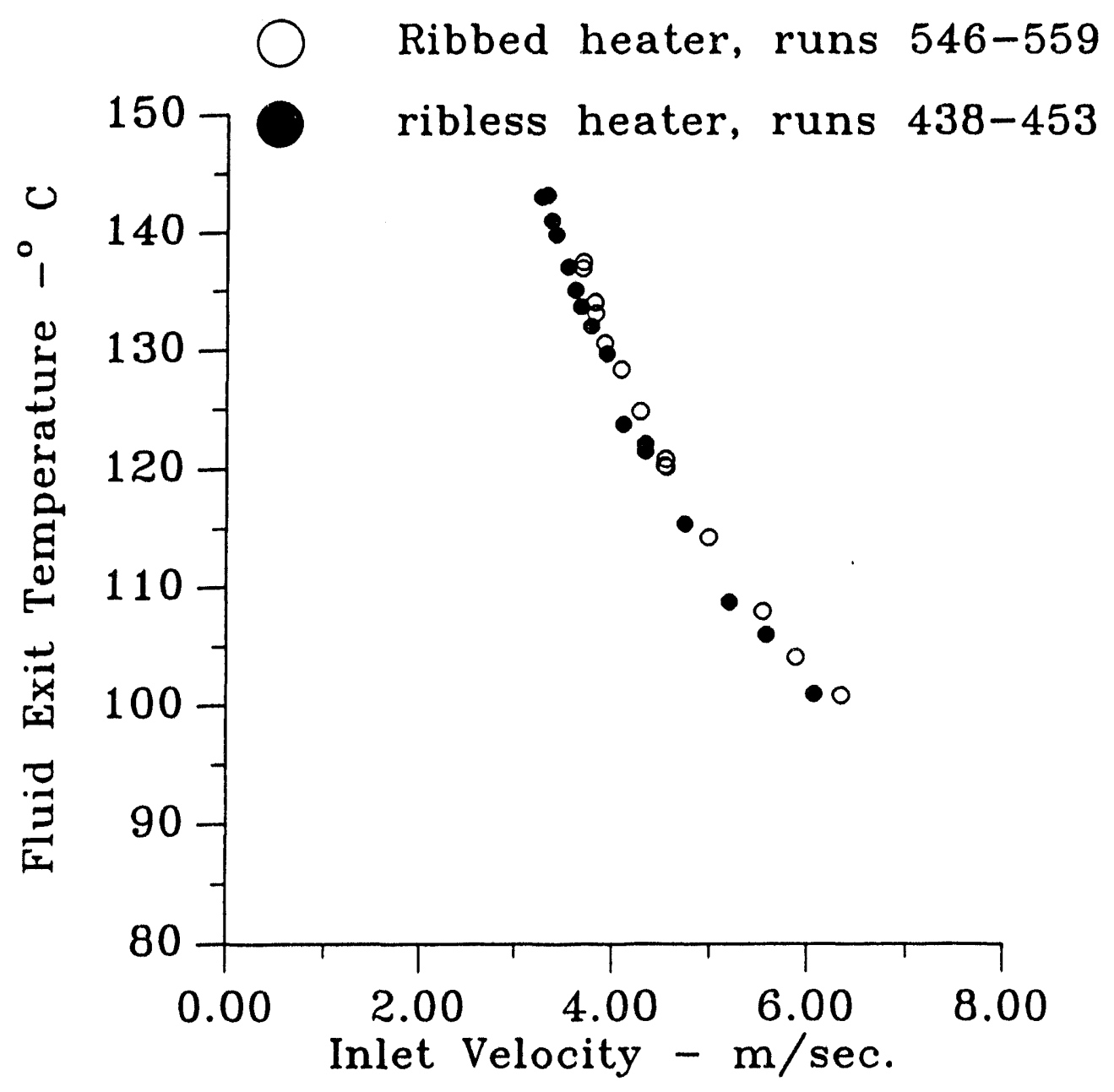

Figure 5 Fluid exit temperature versus velocity, $\mathrm{P}_{\text {exit }}=448 \mathrm{kPa}, \mathrm{T}_{\text {inlet }}=50^{\circ} \mathrm{C}$ flux $=1.26 \mathrm{MW} / \mathrm{m}^{2}$ 


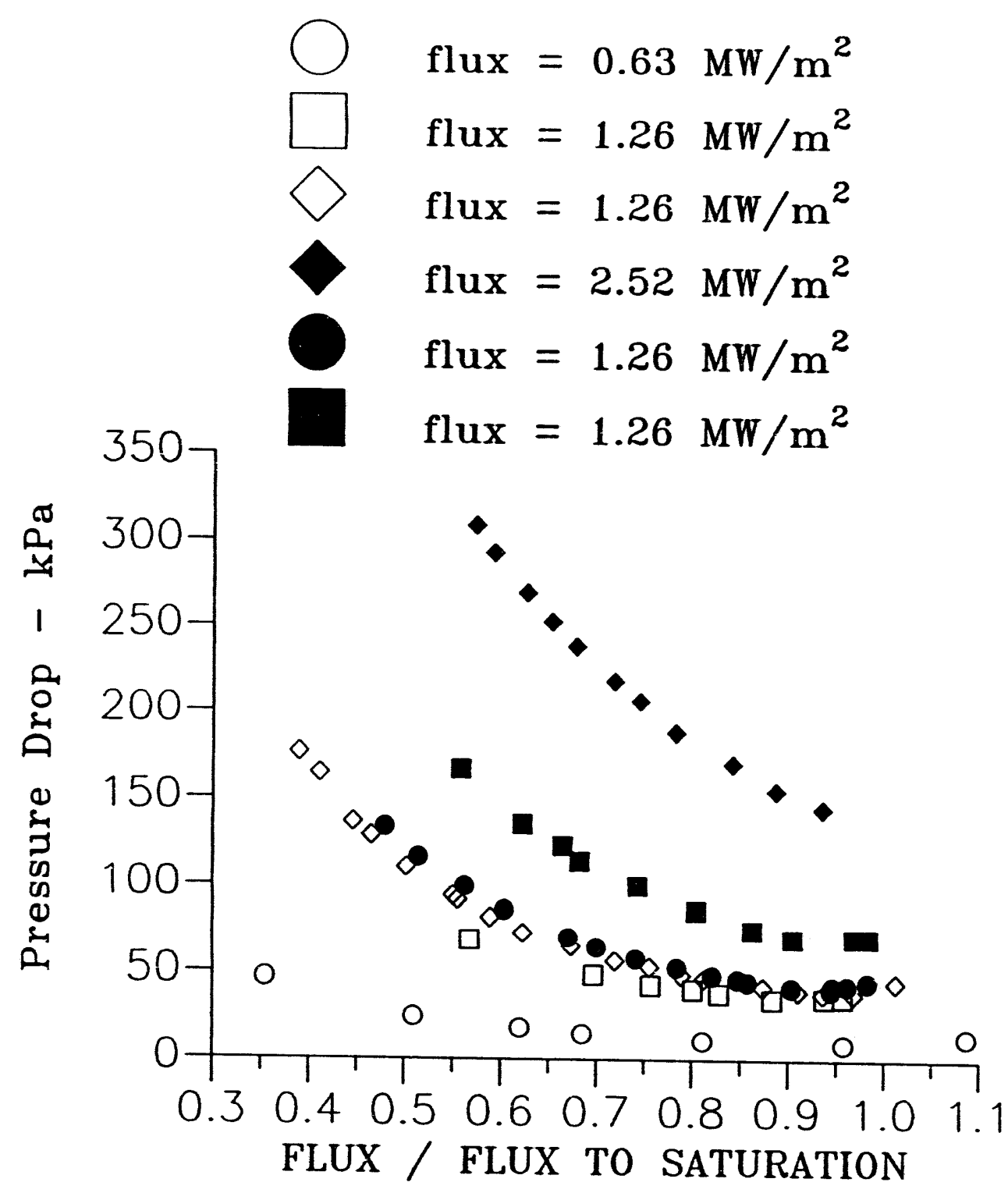

Figure 6 Pressure drop versus $Q_{\text {ratio }}$ ribless test section 


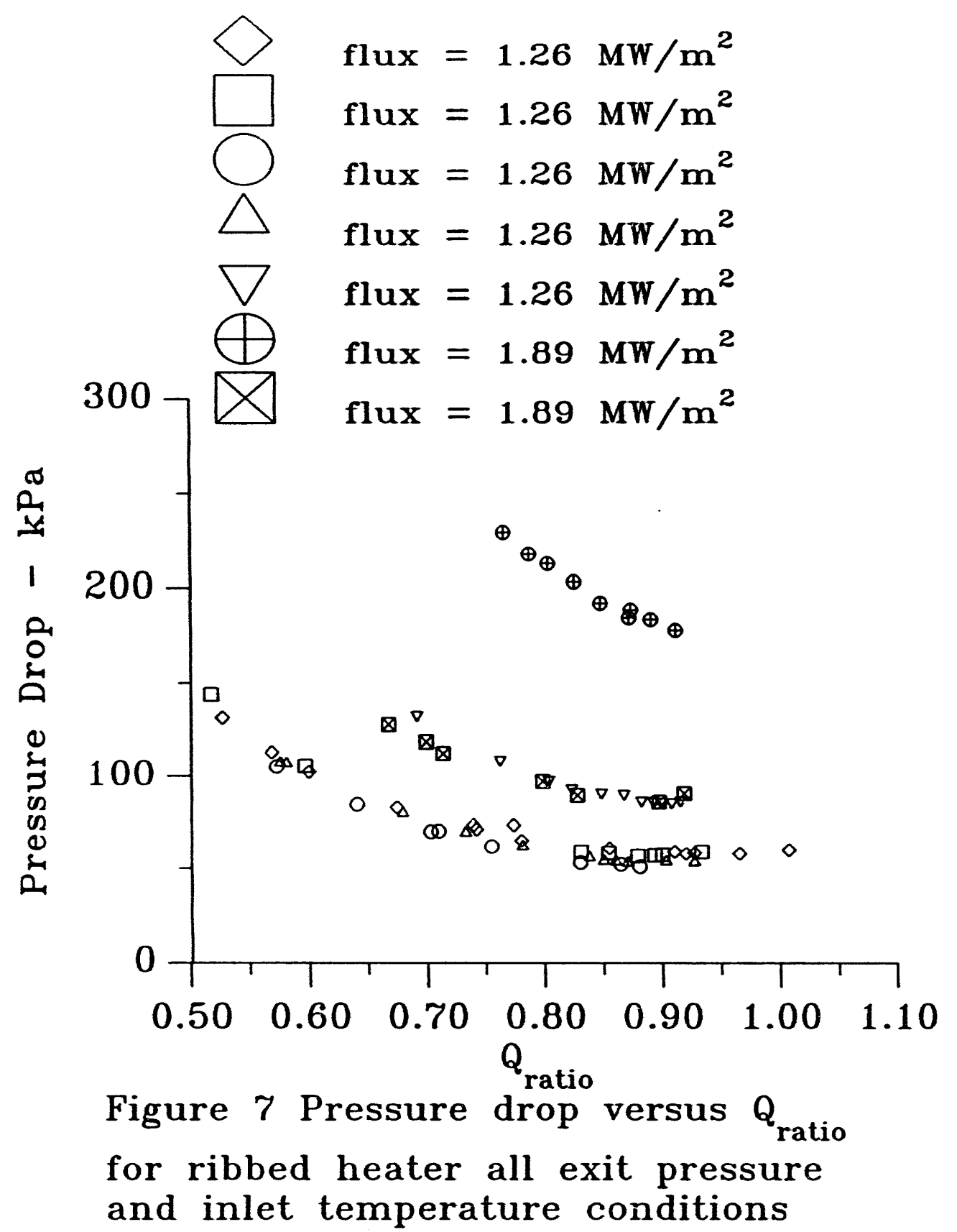




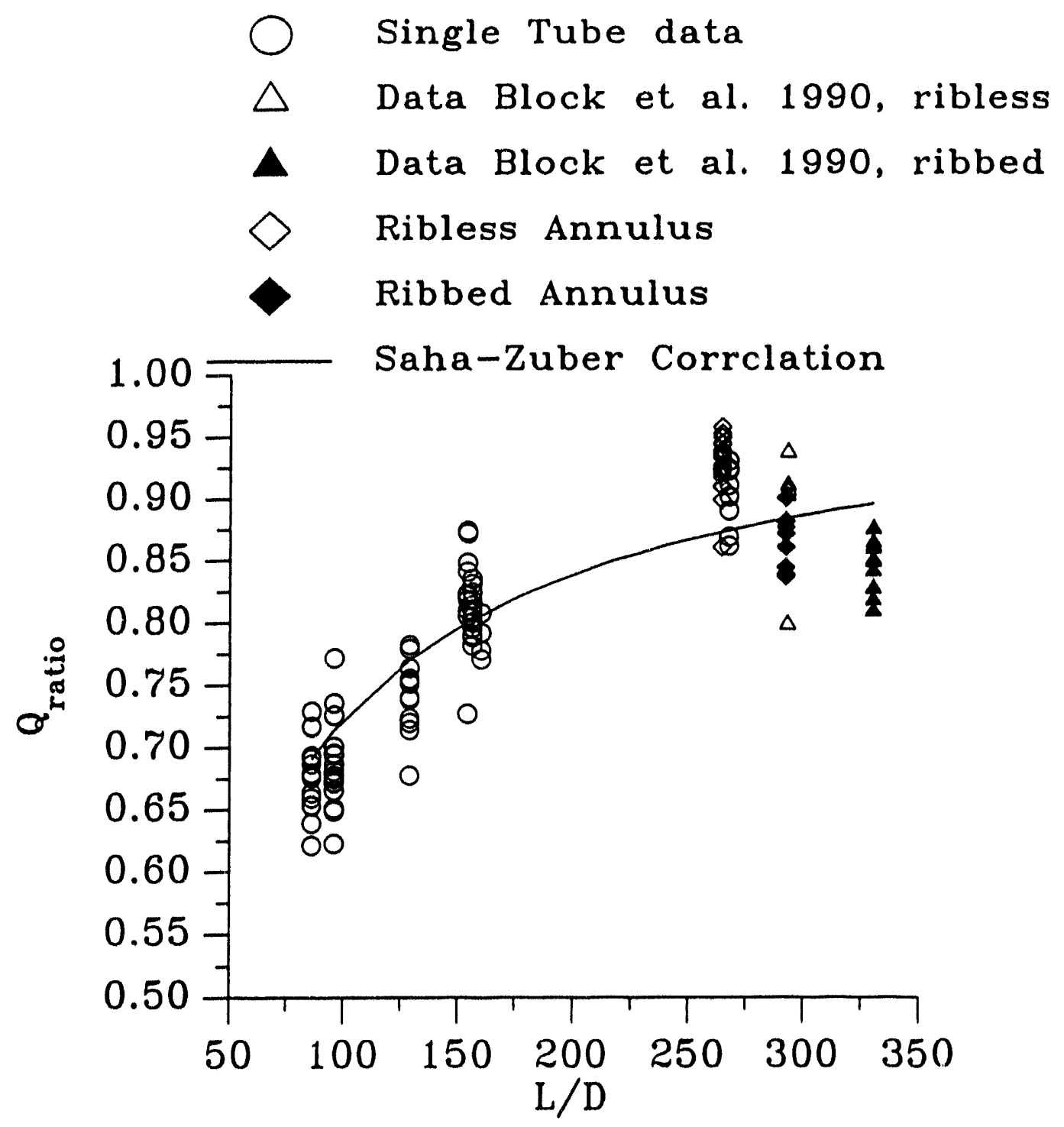

Figure $8 Q_{\text {ratio }}$ at $O F I$ versus $L / D$

for various test sections with uniform heating 


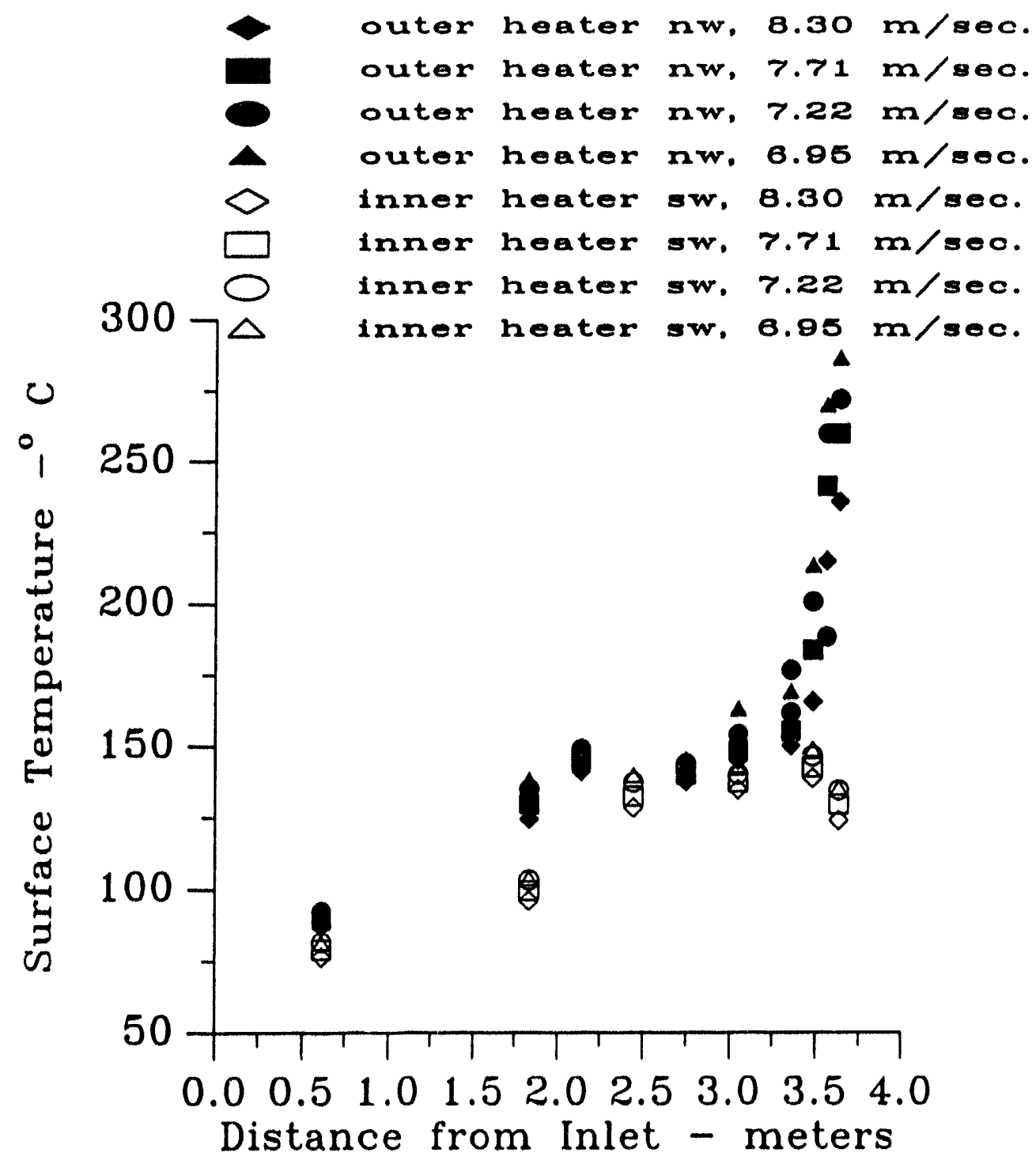

Figure 9 Surface temperature versus

$$
\begin{aligned}
& \text { location, } \mathrm{P}_{\text {exit }}=241 \mathrm{kPa}, \mathrm{T}_{\text {inlet }}=50^{\circ} \mathrm{C} \\
& \text { flux }=1.89 \mathrm{MW} / \mathrm{m}^{2}
\end{aligned}
$$




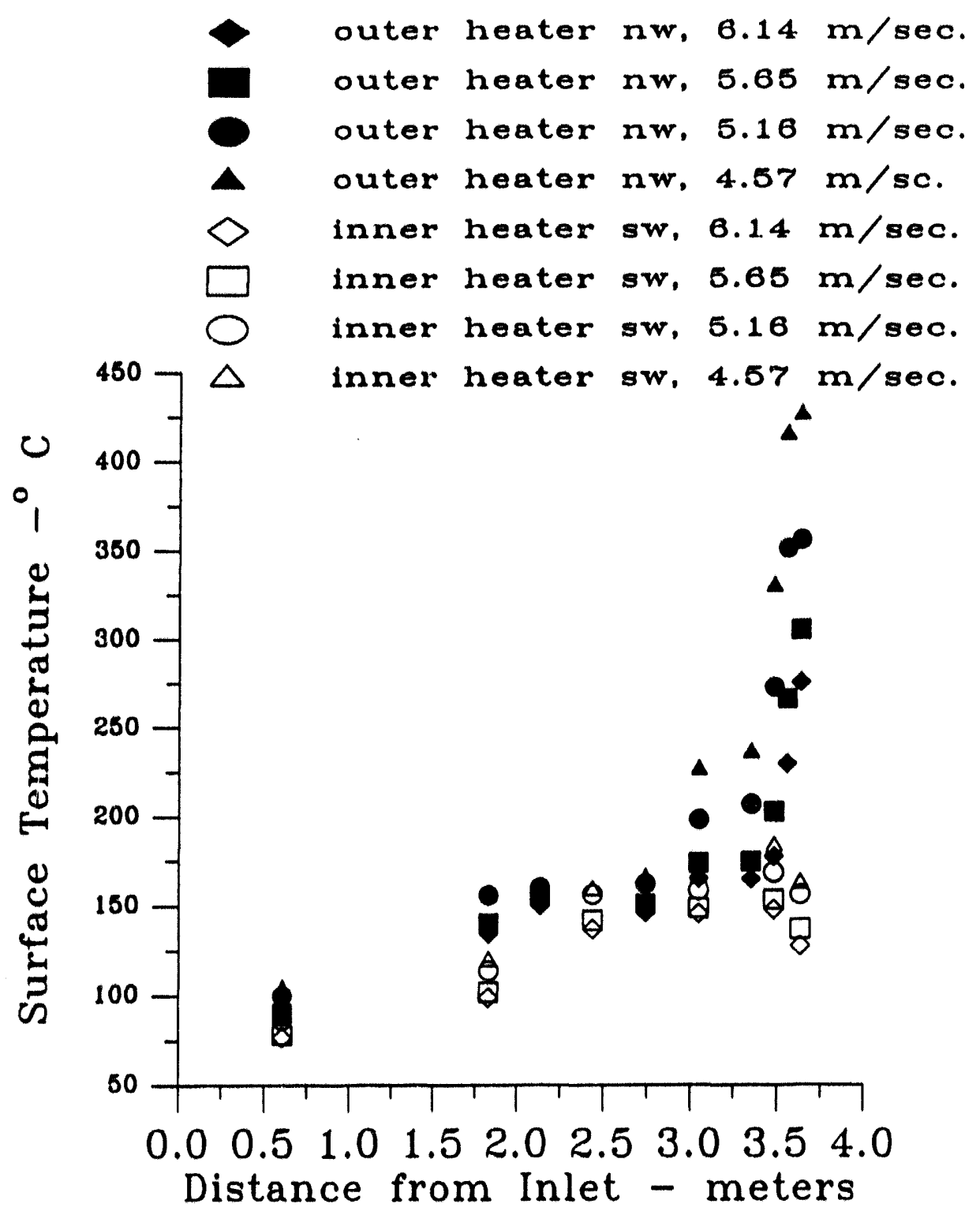

Figure 10 Surface temperature versus

location, $\mathrm{P}_{\text {exit }}=448 \mathrm{kPa}, \mathrm{T}_{\text {inlet }}=29^{\circ} \mathrm{C}$ flux $=1.89 \mathrm{MW} / \mathrm{m}^{2}$ 


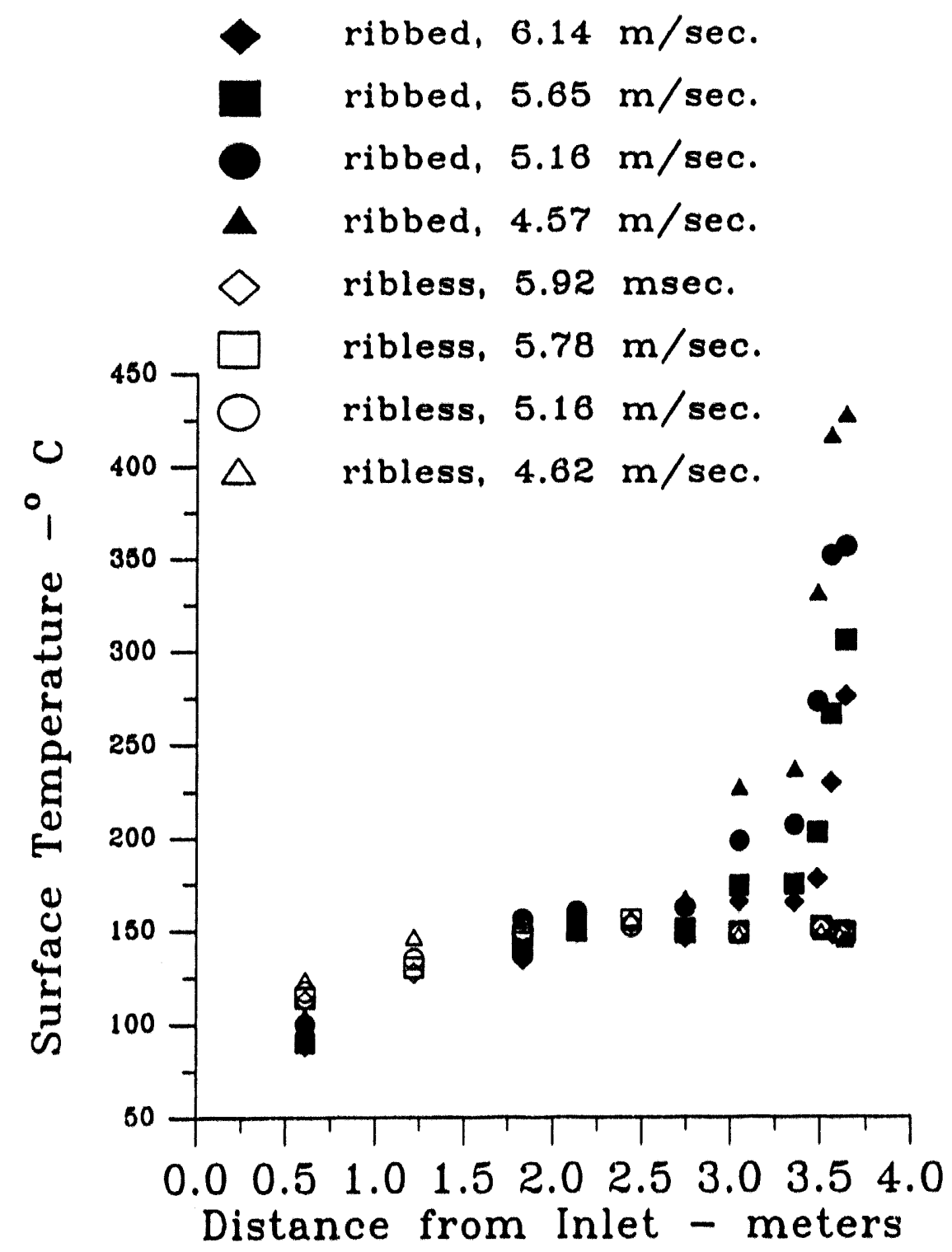

Figure 11 Surface temperature on outer heater $\mathrm{NW}$ versus location, $\mathrm{P}_{\text {exit }}=448 \mathrm{kPa}$,

flux $=1.89 \mathrm{MW} / \mathrm{m}^{2}$ 
$\bigcirc$ OFI, ribless heater

- OFI ribbed heater

* CHF, ribbed heater

$\oplus$ CHF, ribless heater, Knoebel et al.

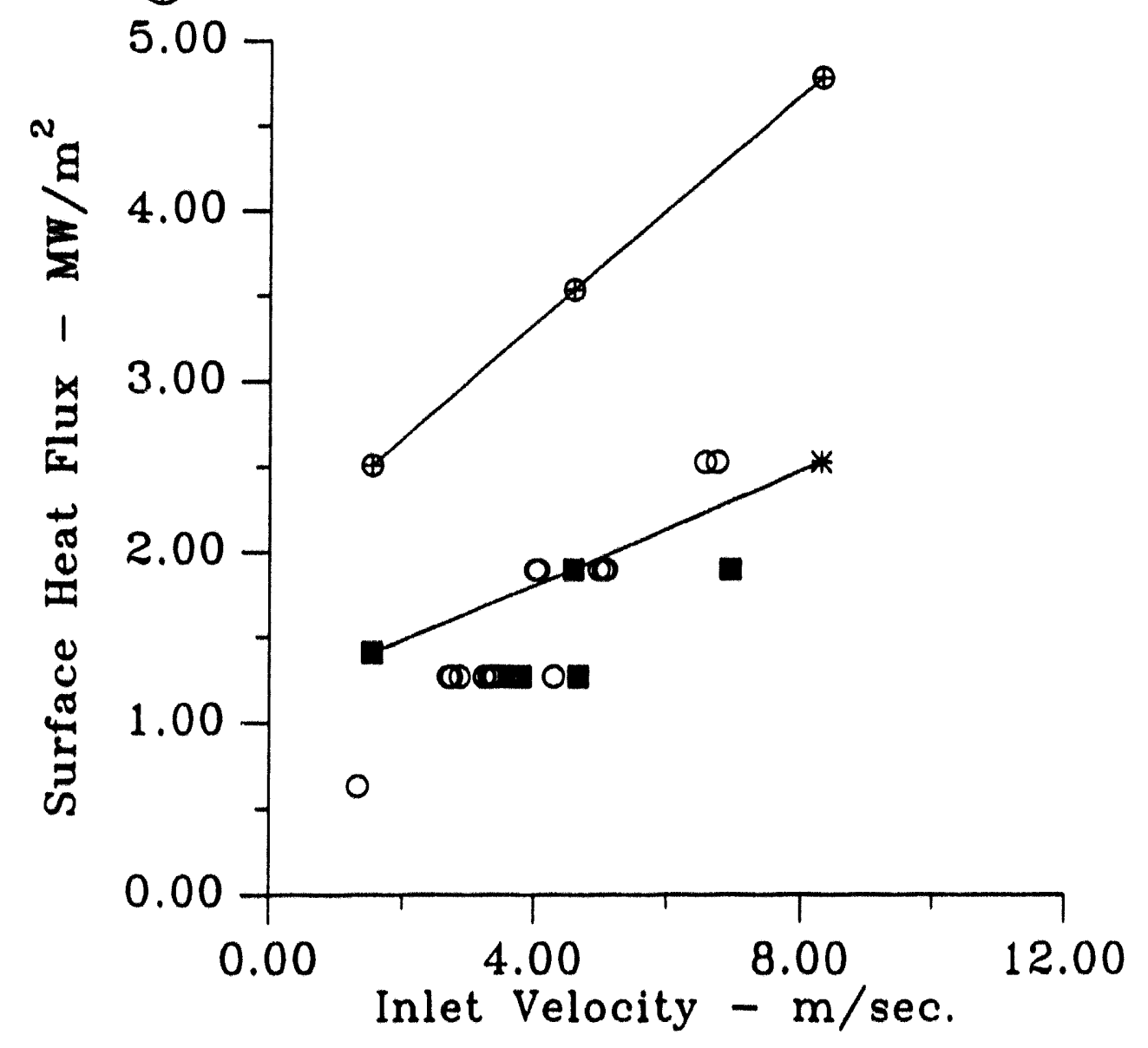

Figure 12 Heater flux versus velocity for $O F I$ and $\mathrm{CHF}$ points 

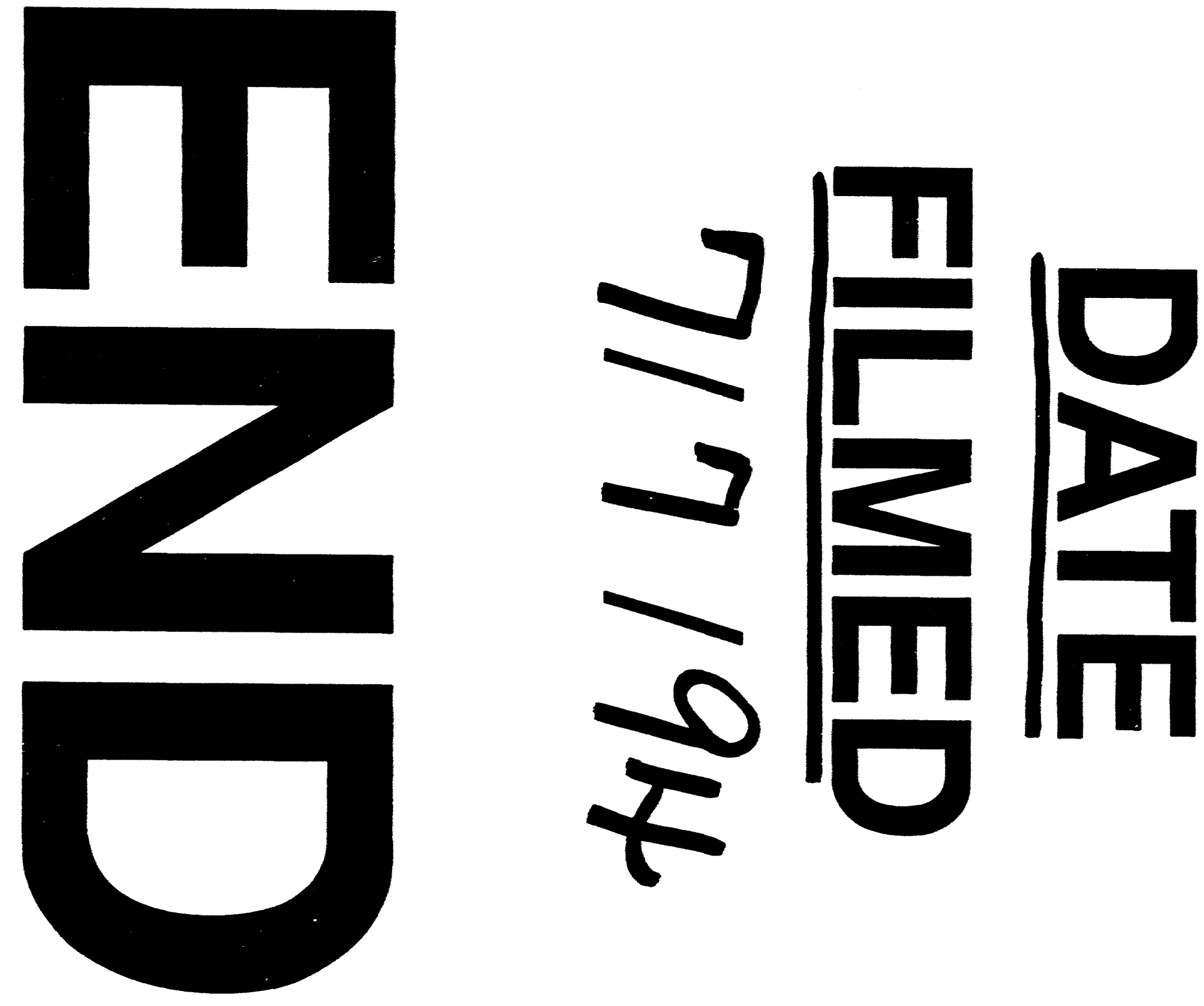


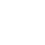

